\title{
Proceeding
}

Supplementary Issue: Spring Conferences of Sports Science. Costa Blanca Sports Science Week, 26-28 April 2018. Calpe. Alicante, Spain

\section{Offensive performance in soccer through lag sequential analysis: The case of a team in the Spanish Second Division-A}

\author{
ROMULO DÍAZ DÍAZ1', EDUARDO JOSÉ RAMOS VERDE¹ $\$, JUAN MANUEL GARCÍA MANSO, \\ TERESA VALVERDE ESTEVE ${ }^{2}$ \\ ${ }^{1}$ Department of Physical Education, Faculty of physical activity and sport sciences, University of Las Palmas \\ de Gran Canaria, Spain \\ ${ }^{2}$ Department of Teaching of Music, Visual and Corporal Expression. University of Valencia, Spain
}

\begin{abstract}
We evaluated the attacking play of a Spanish Second Division-A soccer team (10 league matches). The observational method of Lag Sequential Analysis was used, with exhaustive mutually exclusive categories based on set criteria. From a retrospective perspective, mean length values were detected for the patterns of the LW, RMIF and GK players (max-lag = -3); short for LMIF (max-lag= -1 ), LI and LC (max-lag = -2) and long for FOR (max-lag = -5) and LB, RC and RW (max-lag= -4). The prospective perspective revealed mean lengths for RB, RC and $\mathrm{Cl}$ (max-lag = 3) and short for GK, RMFI and FOR (max-lag = 2). The long patterns correspond to the SSTR, RW, LW and LB players (max-lag =4) and $\mathrm{MCl}$ (max-lag =5). The greater relationships between players, in both perspectives, were generated between the full-backs (RB and LB) and the wingers on their side (RW and LW). For the center-backs (RC and LC), the priority relationships are with the other defensive players on their team. The midfielders (RMIF and LMIF) did not show any bifurcations, complementing each other, since when one acts in the retrospective perspective, his partner does so in prospective. It was observed that the chances of winning grow as the number of shots at goal increases, or the chances of losing decrease. We confirm that Lag Sequential Analysis provides detailed, useful
\end{abstract}

Corresponding author. Department of Physical Education, Faculty of physical activity and sport sciences, University of Las Palmas de Gran Canaria, Campus universitario de Tafira, Las Palmas de Gran Canaria, Spain.

E-mail: eduardo.ramos@ulpgc.es

Supplementary Issue: Spring Conferences of Sports Science. Costa Blanca Sports Science Week, 26-28 April 2018. Calpe. Alicante, Spain.

JOURNAL OF HUMAN SPORT \& EXERCISE ISSN 1988-5202

(C) Faculty of Education. University of Alicante

doi: 10.14198/jhse.2018.13.Proc2.12 
information about attacking play in soccer. Key words: OBSERVATIONAL ANALYSIS, SOCCER, SEQUENTIAL ANALYSIS, OFFENSIVE PERFORMANCE.

\section{Cite this article as:}

Díaz, R., Ramos, E.J., García, J.M., \& Valverde, T. (2018). Offensive performance in soccer through lag sequential analysis: The case of a team in the Spanish Second Division-A. Journal of Human Sport and Exercise, 13(2proc), S269-S282. doi:https://doi.org/10.14198//hse.2018.13.Proc2.12 


\section{INTRODUCTION}

Soccer is a team sport in which two teams of eleven play against each other, establishing a constant confrontation over possession of the ball with the aim of getting it into the opposite team's goal as many times as possible and avoiding it entering their own. In any sport, performance analysis is a fundamental tool for success. The collection of information during the competition is the starting point for appropriate planning of training and future games (Lago, 2008).

Throughout the match, the teams alternate two patterns of play or behavior continuously throughout the game (Gréhaigne, 2001): attacking and defensive. Attacking, or offensive, play has been the main objective of research that has analyzed this sport from a tactical or strategic point of view. The offensive phase is the one that encompasses all the actions carried out by a team to try to retain possession of the ball and progress towards the opposite team's goal with the aim of scoring a goal (Sánchez-Flores, 2014). It starts when the ball is put into play (kickoff, goal kick, throw-in, etc.) or possession of the ball is regained. It ends when a goal is scored, a violation is committed, or possession is lost.

In socio-motor sports such as soccer, each confrontation is characterized by constant dynamic interactions between the players of both teams (Araújo, Duarte, Davids and Hristovski, 2006; Lames and McGarry, 2007; Duarte, Araújo, Folgado, Esteves, Marques, and Davids, 2013; Couceiro, Clemente, Martins, and Machado, 2014; Stöckl, Plück, and Lames 2017). The game could be interpreted as a complex network with a changing structure and topology, where the flow of actions does not remain stable (either in time or in space). From this point of view, players, like the nodes of a network of these characteristics, interact numerous times and in a non-linear way, using the ball as a connecting element as they try to beat their rivals through constant mechanisms of self-organization, where the degree of predictability is low even though the actions respond to a previously established underlying behavior (De Saá-Guerra, Martín-González, Arjonilla, Sarmiento, Rodríguez-Ruiz and García-Manso, 2003; Garganta, 2009; Pena and Touchette, 2012).

The first methodological strategies of performance analysis were taken from individual sports, in which technical and biomechanical criteria were determining factors. However, when applied to team sports these models do not provide an in-depth understanding of the internal logic of the game. If we accept the argument that performance in soccer is the result of a complex interrelation of multiple variables, an analysis of these characteristics would prevent us from understanding all the complexities of the game (Garganta, 2000).

Nowadays, different methods are available (Data Modeling, Data Mining, Information Visualization and Visual Analytics) that make it possible to extract information, analyze and diagnose the effectiveness of the different phases of the game and the influence that each of them has on the final result of the match (Stein, Janetzko, Seebacher, Jäger, Nagel, Hölsch, Kosub, Schrek, Keim and Grossniklaus, M., 2017). The applicability and usefulness of these methods has been enhanced by the quality of data available from each game and the technological advances in monitoring (Castellano, Perea, Alday, and Mendo, 2008; Arriaza and Zuñiga, 2016).

One of the most common strategies used in recent years has been the observational method (Anguera, 1990; Anguera and Blanco, 2003; Anguera, Hernández-Mendo, 2015) and the possibilities provided by the technique known as Lag Sequential Analysis (Bakeman and Gottman, 1997; Castellano and Mendo, 2000; Silva, Sánchez Bañuelos, Garganta and Anguera, 2005; Barreira, Garganta, Castellano, Prudente, and Anguera, 2014.). Observation of the behaviors and events that take place during the game makes it possible to systematize and specify the interactions between team members and evaluate explanatory variables about 
what happened during the game. From these, we can establish what is really important and discard what has no direct significance or is simply not fundamental for what we wish to study.

The aim of this study is to analyze, through Lag Sequential Analysis, the attacking play shown by a professional Spanish soccer team in Second Division-A in official matches, in which they played at home.

\section{METHOD}

To carry our this study, we used an observational method through an active, non-participant observation process, in which the categories of each of the set criteria are exhaustive and mutually exclusive; (Anguera, 1990; Anguera, and Blanco-Vilaseñor, 2003; Anguera, and Hernández-Mendo, 2015). According to the structure proposed by Anguera, Blanco, Hernández-Mendo and Losada (2014), the work would be situated in Quadrant IV, which includes it among Nomothetic (home team and its rivals), Monitoring (10 Second Division-A matches against different rivals) and Multidimensional (dimensions explained in the criteria of the observation instrument) studies. In the case of motor interactions, the results are shown by lag sequential analysis. Lags are represented in both the retrospective (moments prior to participation) and prospective (moments after participation) modes. Lag levels range between $\mathrm{R}-5$ and +5 , not considering 0 lag as belonging to the behavior of the evaluated player.

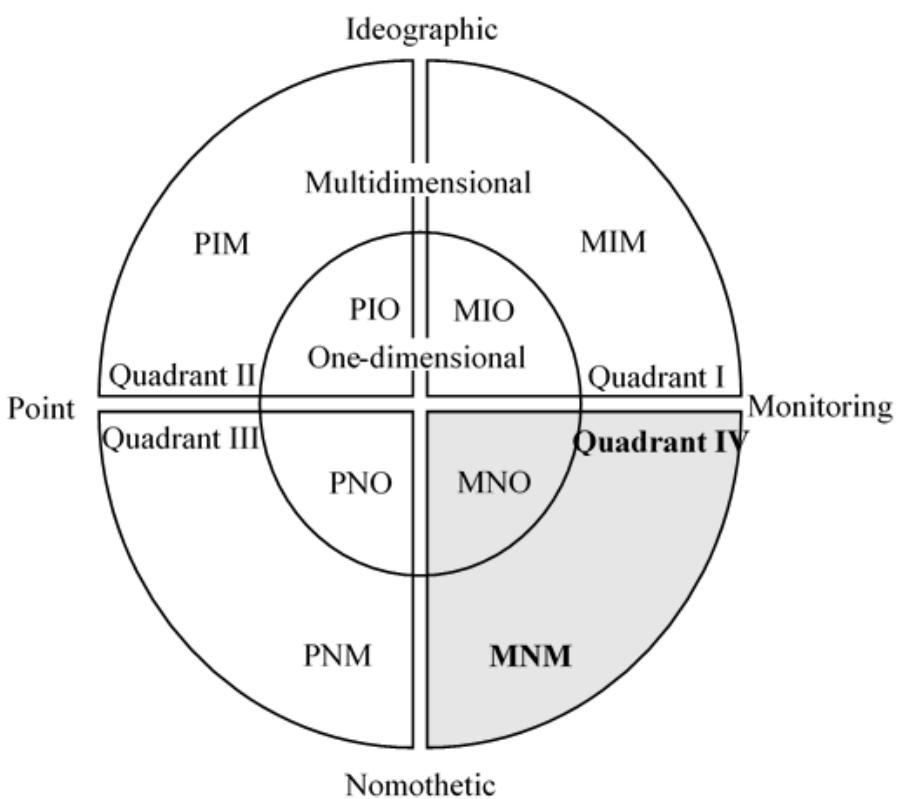

Figure 1. Graphic representation of the eight observational designs, from the superposition of the Units of the study criteria (represented by the vertical diameter), Temporality (represented by the horizontal diameter) and Dimensionality (represented by the concentric circles). There are eight areas, which correspond to the eight observational designs. Adapted from Anguera (2011).

\section{Participants}

Spanish professional soccer is structured into different categories (First Division and Second Division-A) with a regular competition system (leagues with a double round-robin system). For the study, 10 randomly 
selected Second Division-A matches were analyzed, in which the observed team played at home against ten different rival teams from the same category (results: 4 won; 5 tied; 1 lost). The games were recorded with a professional camera to obtain a wide view of the playing field and so that the maximum number of players were visible in the image at all times.

Table 1. Observation tool with identification of the criteria and the different categories.

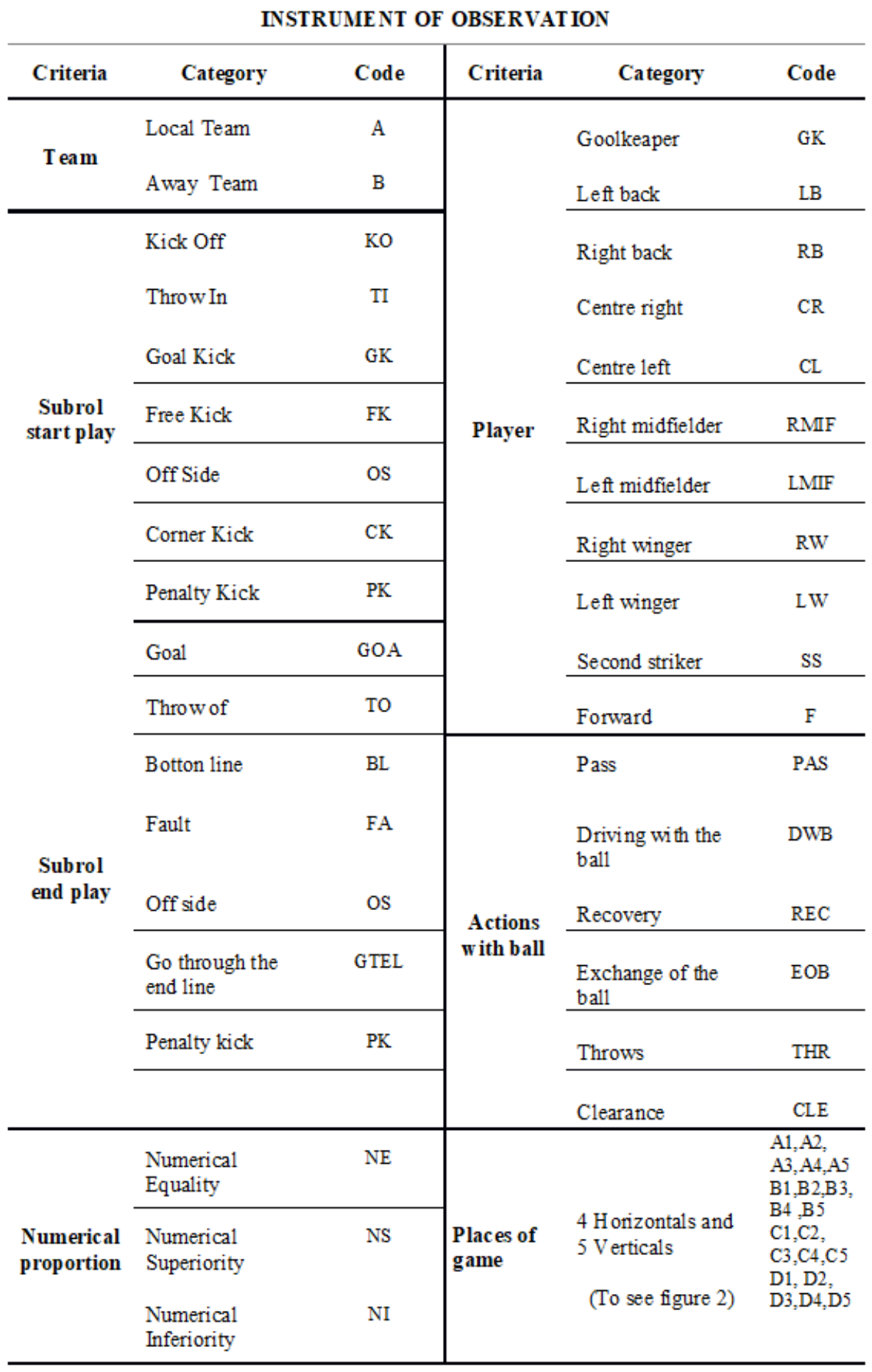




\section{Instrument of observation}

We use the SOCCAF v.5 system (Robles, 2012) for the Development of our observational tool. We used and adapted several of the criteria proposed by the author, which helped us to design our own ad hoc observation tool. The criteria used were: 1: Team; 2: Start of play; Criterion 3: End of play; 4: Actions with the ball; 5: Players; 6: Numerical proportion; 7: Areas of play.

Figure 2. Graphic representation of the twenty areas of play (4 horizontal and 5 vertical) established for the areas of play criterion of the observation instrument.

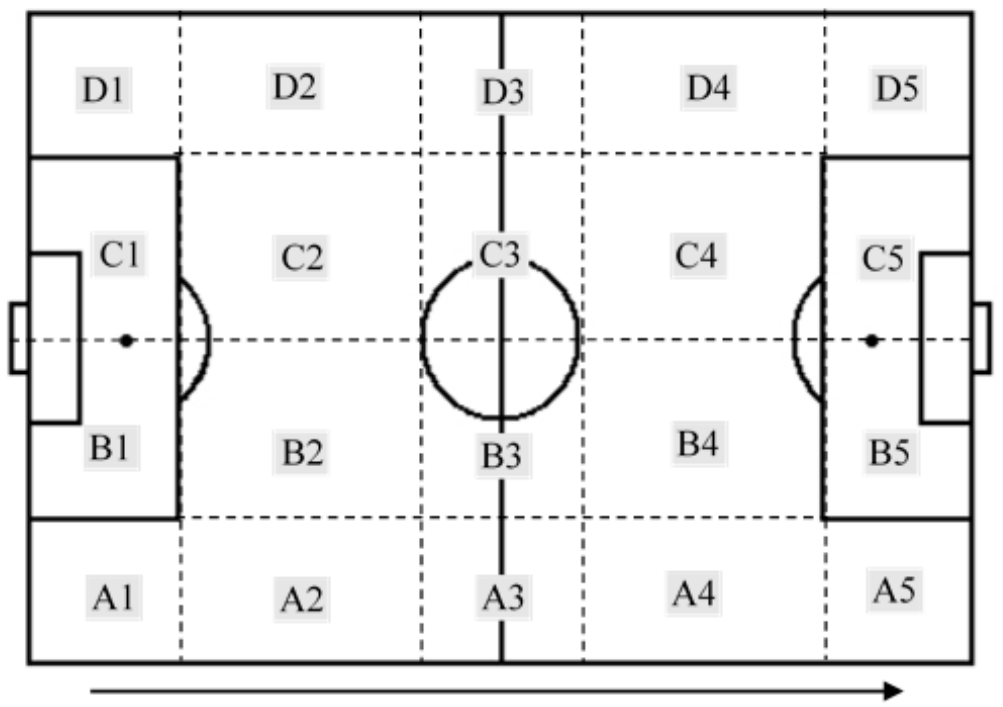

Attack direction

The LINCE v.1.1 program (Gabin, Camerino, Anguera and Castañer, 2012) is the recording instrument used to visualize and code the matches, while lag sequential analysis was determined with the GSEQ 5.1. software.

\section{Control of the quality of the data}

The findings of research cannot be more reliable and valid than the evaluation procedures by which they are obtained (Kent and Foster, 1977). Two guidelines have been used to assess the quality of the data (BlancoVillaseñor and Anguera, 2003):

Qualitative: consensual agreement has been used (4 experienced observers), since this strategy is usually used in the observational method (Anguera, 1990).

Quantitative: Cohen's kappa coefficient (Cohen, 1960) was used to calculate intraobserver reliability, a measure of agreement between two observations for qualitative variables. For its evaluation, the scale suggested by Landis and Koch (1977) was used. The concordance criteria used were: very good agreement 0.81-1.00; good agreement 0.61-0.80; moderate agreement 0.41-0.60; low agreement 0.21-0.40; insignificant 0.00-0.20; no agreement $<0.0$. The data were exported to the GSEQ 5.1 software program (Quera, Bakeman and Gnisci, 2007) to produce an error detection file and calculate the reliability (Cohen's Kappa coefficient). The results obtained are between 0.76 and 1.00 . 


\section{RESULTS}

Table 2. shows the behavior pattern in the relationships and interactions between players on the same team.

Table 2. Adjusted residuals of the interactions, retrospective (left) and prospective (right), between the players of the home team. Lag sequential analysis allows patterns of behavior to be identified with a greater probability than that expected due to the effect of chance with $\mathrm{p}<.05$.Values above 1.96 are shown in parentheses.

\begin{tabular}{|c|c|c|c|c|c|c|c|c|c|c|}
\hline \multicolumn{11}{|c|}{ LOCAL TEAM PLAYERS CRITERIA } \\
\hline \multicolumn{5}{|c|}{ RETROSPECTIVE } & & \multicolumn{5}{|c|}{ PROSPECTIVE } \\
\hline$R=-5$ & $R=-4$ & $R=-3$ & $R=-2$ & $R=-1$ & C.C. & $R=1$ & $R=2$ & $R=3$ & $R=4$ & $\mathrm{R}=5$ \\
\hline & & $\begin{array}{c}\mathrm{RC} \\
(2,22)\end{array}$ & \begin{tabular}{|c}
$\mathrm{RC}$ \\
$(2,49)$
\end{tabular} & $\varnothing$ & GK & $\begin{array}{c}\text { LC } \\
(4,03)\end{array}$ & $\begin{array}{c}\text { LC } \\
(4,03) \\
\text { LB } \\
(3,24) \\
\text { RC } \\
2,96)\end{array}$ & & & \\
\hline & $\begin{array}{c}\mathrm{RW} \\
(2,19)\end{array}$ & $\begin{array}{c}\mathrm{RW} \\
(2,86)\end{array}$ & \begin{tabular}{|c} 
RC \\
$(4,16)$ \\
RW \\
$(3,87)$
\end{tabular} & $\begin{array}{c}\text { RC } \\
(2,19) \\
\text { WR } \\
(2,03)\end{array}$ & RB & $\begin{array}{c}\text { RW } \\
(4,32) \\
\text { RC } \\
(3,91)\end{array}$ & $\begin{array}{c}\text { RW } \\
(5,87) \\
\text { RC } \\
(2,73)\end{array}$ & $\begin{array}{l}\text { FOR } \\
(2,46)\end{array}$ & & \\
\hline & & & \begin{tabular}{|c} 
GK \\
$(3,24)$ \\
LW \\
$(2,83)$ \\
LC \\
$(2,47)$ \\
LMF \\
$(2,3)$
\end{tabular} & $\begin{array}{l}\text { LC } \\
(3,8) \\
\text { MCI } \\
(2,5)\end{array}$ & LB & $\begin{array}{c}\text { WL } \\
(7,09) \\
\text { LC( } \\
2,69)\end{array}$ & $\begin{array}{c}\text { LW } \\
(7,51)\end{array}$ & $\begin{array}{l}\mathrm{LW} \\
(3,42)\end{array}$ & $\begin{array}{c}\mathrm{CD} \\
(2,38)\end{array}$ & \\
\hline & $\begin{array}{c}\text { LB } \\
(2,18)\end{array}$ & $\begin{array}{c}\text { LC } \\
(2,05)\end{array}$ & \begin{tabular}{|c} 
RB \\
$(2,73)$ \\
GK \\
$(2,96)$
\end{tabular} & $\begin{array}{c}\text { RB } \\
(3,91) \\
\text { LC } \\
(2,96)\end{array}$ & $\mathrm{RC}$ & $\begin{array}{c}\text { LC } \\
(5,66) \\
\text { RB } \\
(2,19)\end{array}$ & $\begin{array}{c}\mathrm{RB} \\
(4,16) \\
\text { LC } \\
(4,13) \\
\text { GK } \\
(2,49) \\
\end{array}$ & $\begin{array}{c}\text { GK } \\
(2,22)\end{array}$ & & \\
\hline & & & \begin{tabular}{|c} 
GK \\
$(4,5)$ \\
RC \\
$(4,13)$
\end{tabular} & $\begin{array}{c}\mathrm{RC} \\
(5,66) \\
\text { GK } \\
(4,03) \\
\text { LB } \\
(2,69)\end{array}$ & LC & $\begin{array}{c}\text { LB } \\
(3,82) \\
\text { RC } \\
(2,96)\end{array}$ & $\begin{array}{c}\text { LB } \\
(2,83)\end{array}$ & $\begin{array}{c}\text { RC } \\
(2,05)\end{array}$ & & \\
\hline & & $\begin{array}{c}\text { RW } \\
(2,35)\end{array}$ & $\begin{array}{c}\text { RW } \\
(2,49)\end{array}$ & $\varnothing$ & RMIF & $\varnothing$ & $\begin{array}{l}\text { LW } \\
(2,6)\end{array}$ & & & \\
\hline & & & & $\begin{array}{c}\text { LC } \\
(2,2)\end{array}$ & LMIF & $\begin{array}{c}\text { LB } \\
(2,52)\end{array}$ & $\begin{array}{c}\text { LB } \\
(2,52)\end{array}$ & $\begin{array}{c}\text { LW } \\
(2,67)\end{array}$ & $\varnothing$ & $\begin{array}{c}\text { FOR } \\
(3,00)\end{array}$ \\
\hline & $\begin{array}{c}\text { LW } \\
(2,54) \\
\text { SSTRI } \\
(2,23)\end{array}$ & $\begin{array}{c}\text { SSTR } \\
(3,65) \\
\text { LW } \\
(2,29)\end{array}$ & \begin{tabular}{|c} 
RB \\
$(5,78)$ \\
RMIF \\
$(2,6)$ \\
FOR \\
$(2,46)$ \\
\end{tabular} & $\begin{array}{c}\mathrm{RB} \\
(4,32)\end{array}$ & RW & $\begin{array}{c}\text { RB } \\
(2,03)\end{array}$ & $\begin{array}{c}\text { RB } \\
(3,87) \\
\text { RMFI } \\
(2,49) \\
\text { FOR } \\
(2,28)\end{array}$ & $\begin{array}{c}\text { RB } \\
(2,86) \\
\text { RMFI } \\
(2,35)\end{array}$ & $\begin{array}{c}\text { RB } \\
(2,19)\end{array}$ & \\
\hline & & $\begin{array}{c}\text { LB } \\
(3,42) \\
\text { LMFI } \\
(2,67)\end{array}$ & $\begin{array}{l}\text { LB } \\
(7,61)\end{array}$ & $\begin{array}{c}\text { LB } \\
(7,09)\end{array}$ & LW & $\begin{array}{c}\text { LB } \\
(2,47)\end{array}$ & $\begin{array}{c}\mathrm{RW} \\
(2,29)\end{array}$ & $\varnothing$ & $\begin{array}{c}\text { RW } \\
(2,54) \\
\text { FOR } \\
(2,07)\end{array}$ & \\
\hline & & & & & SSTR & $\varnothing$ & $\varnothing$ & $\begin{array}{c}\text { BD } \\
(3,64)\end{array}$ & $\begin{array}{c}\text { BD } \\
(2,23)\end{array}$ & \\
\hline $\begin{array}{l}\text { LMFI } \\
(3,00)\end{array}$ & $\begin{array}{c}\text { LW } \\
(2,07)\end{array}$ & $\begin{array}{c}\text { RB } \\
(2,46)\end{array}$ & $\varnothing$ & $\varnothing$ & FOR & $\varnothing$ & $\begin{array}{c}\text { RW } \\
(2,46)\end{array}$ & & & \\
\hline
\end{tabular}


As can be seen, for the retrospective perspective, the values of the length of the pattern are medium for the LW, RMIF and GK players (max-lag $=-3$ ); short for the LMCI player (max-lag $=-1$ ) and LB and LC players (max-lag = -2); long for the FOR player (max-lag = -5), and the RB, RC and RW players (max-lag = -4). The SSTR player does not activate any categories.

The number of different categories that form the patterns varies between 1 and 4 . The players establish different patterns depending on the position they occupy in the game (in all the matches observed, the dominant formation was 1-4-2-3-1, with the attacking variant 1-4-4-2). The full-backs form patterns, mainly, with the wingers and the defenders (Pattern of RB with RC and RW; Pattern of LB with LC, LMIF, LW and GK). The centre-backs form patterns with the other defenders (Pattern of RC with RB, GK, LC and LB; Pattern of LC with RC, GK and LB). The wingers employ more diverse patterns (Pattern of RW with RB, RMIF, SSTR, FOR and LW; Pattern of LW with LB and LMIF). The FOR player, however, establishes simpler patterns (Patterns of FOR with LMFI, LW and RB).

Regarding the itineraries of the patterns, it should be noted that in the RB, LB, RC, LC, RW and LW positions bifurcations were detected in one or more lags, which shows the high variability of associations created by these players. On the other hand, the GK, RMIF, LMIF and FOR players show more stable associations, causing simpler ways to connect with the itineraries and not requiring bifurcations. In the team analyzed, the SSTR position is not activated with other positions in the matches evaluated.

For the prospective perspective, the length values of the patterns are medium for RB, RC and LC (maxlag = 3) and short for the GK, RMIF and FOR positions (max-lag = 2). The players with long patterns are SSTR, RW, LW and LB (max-lag = 4) and $\mathrm{MCl}$ (max-lag = 5). The number of categories that form the patterns in this perspective ranges between 1 and 3 . The players created these patterns based on the positions occupied in the team's game system (Table 2).

In relation to the itineraries, in the GK, RB, LB, RC, LC, RW and $L W$ positions there were bifurcations in one or more lags, which shows high variability in the behavior of these players. In the other positions, the itineraries to reach these players are unidirectional (Table 2).

Table 3 shows the number of actions performed by each player in the home team studied, obtaining information on the importance of certain members of the team.

In terms of the number of actions, a large number is observed for two players who occupied the positions of midfielder (RMFI and LMFI). MFI performed 371 (12.51\%) of the total passes (10 matches), with 699 actions taken. We think that both players had a high probability of relating to the other members of the team because of their spatial location, which is determined by the tactical organization of the team. The third player in order of importance in terms of passing, is the left-back (LI) with a total of 337 passes (11.36\%). In terms of total actions, he is surpassed by the wingers (RW and LW) due to the greater influence of these players on driving the ball.

In terms of dribbling, the wingers (RW and LW), in addition to the player who occupies the position of attacking midfielder (SSTR), are the ones who make the most use of this resource. It is the responsibility of all the players to drive the ball, but for some of them (e.g. wingers) this technical action has greater weight and importance than for others. There are players who, due to their game play, tactical involvement or technical abilities, have greater responsibility when carrying out certain technical/tactical actions. In the team studied, the wingers (RW and LW) and the forward (FOR) are the ones who scored the highest percentage in the ten 
games analyzed.

Table 3. A ctions with the ball by players of the home team. Frequencies and percentages of each of the actions determined in our observational instrument are presented for each of the players in the total number of matches.

\begin{tabular}{|c|c|c|c|c|c|c|c|c|c|c|c|c|}
\hline \multirow{2}{*}{ PLA. } & \multicolumn{2}{|c|}{ Pass } & \multicolumn{2}{|c|}{ Dribbling } & \multicolumn{2}{|c|}{$\begin{array}{l}\text { Driving with } \\
\text { the ball }\end{array}$} & \multicolumn{2}{|c|}{ Clearance } & \multicolumn{2}{|c|}{ Recovery } & \multicolumn{2}{|c|}{ Shoot } \\
\hline & Frec & $\%$ & Frec & $\%$ & Frec & $\%$ & Frec & $\%$ & Frec & $\%$ & Frec & $\%$ \\
\hline GK & 187 & 6,30 & 0 & 0 & 48 & 3,48 & 29 & 6,55 & 103 & 15,28 & 0 & 0 \\
\hline RB & 272 & 9,17 & 5 & 1,68 & 96 & 6,97 & 76 & 17,16 & 83 & 12,31 & 8 & 5,26 \\
\hline LB & 337 & 11,36 & 12 & 4,03 & 125 & 9,07 & 66 & 14,90 & 54 & 8,01 & 6 & 3,95 \\
\hline $\mathrm{RC}$ & 210 & 7,08 & 3 & 1,01 & 67 & 4,86 & 69 & 15,58 & 74 & 10,98 & 2 & 1,32 \\
\hline LC & 248 & 8,36 & 1 & 0,34 & 60 & 4,35 & 63 & 14,22 & 79 & 11,72 & 3 & 1,97 \\
\hline RMFI & 371 & 12,51 & 37 & 12.42 & 162 & 11,76 & 38 & 8.58 & 70 & 10,39 & 21 & 13,82 \\
\hline LMIF & 364 & 12,27 & 22 & 7,38 & 155 & 11,25 & 36 & 8,13 & 87 & 12,91 & 14 & 9,21 \\
\hline RW & 279 & 9,41 & 59 & 19,80 & 211 & 15,31 & 21 & 4,74 & 34 & 5,04 & 28 & 18,42 \\
\hline LW & 249 & 8,40 & 66 & 22,15 & 198 & 14,37 & 25 & 5,64 & 50 & 7,42 & 24 & 15,79 \\
\hline SSTR & 271 & 9,14 & 63 & 21,14 & 153 & 11,10 & 12 & 2,71 & 27 & 4,01 & 12 & 7,89 \\
\hline FOR & 178 & 6,00 & 30 & 10,07 & 103 & 7,47 & 8 & 1,81 & 13 & 1,93 & 34 & 22,37 \\
\hline
\end{tabular}

Where: Frec is the total actions per player and \%, the percentage with respect to the total team members. The values in bold represent the most significant ones in each of the aspects analyzed.

\section{DISCUSSION}

Team play has been shown to be the key element of success in attack, interactions between the players and passing being the most important indicators for describing a team's style of play. In recent years, successful teams have been transforming the patterns of attack that precede the scoring of the goal. Specifically, they have evolved from the use of more individual behaviors (such as dribbling or driving the ball) to fundamentally team behaviors such as centers or short passes typical of associative playing styles such as "tiki-taka" (Gyarmati, Kwak and Rodríguez, 2014) and defense/attack transitions along the side corridors (Grant, Reilly, Williams and Borrie, 1998; Griffiths, 1999; Barreira, Ribeiro, Garganta and Anguera, 2010; Machado, Barreira and Garganta, 2011).

In this regard, the study of interactions between the players of the studied team has allowed us to identify the most frequent relationships between them. When the full-backs (RB and LB) have been taken as a criterion, a clear relationship with the wingers on the same side (RW and $L W$ ) is shown, in both the retrospective and prospective perspectives. For the centre-backs (Rc and LC), the priority relationships are with the other defensive players in their team. In general, and for both perspectives, the behavior patterns are short, coinciding with the data provided by Robles and Castellano (2012) when studying the Spanish national team that participated in the 2008 European Championship and the 2010 World Championship.

The players who occupy midfield positions (RMIF and LMIF) showed patterns without bifurcations, complementing each other in their participation, since when one acts primarily in the retrospective 
perspective, his partner does so in the prospective. These data give us information about the distribution of functions of two players who, although acting in similar areas of the field, are usually players that complement each other in their function. In this regard, one of them acts with more freedom to reach areas of the opposite goal, while his partner gives the defensive balance to the team. The fact that they do not present bifurcations suggests that the relationships that they establish with the other players allows them to generate varied relationships with attacking or defensive players as a consequence of the spatial position in which they act. Several studies coincide in stating that these are the most important players in a soccer team (Duch, Waitzman and Amaral, 2010; Kannekens, Elferink-Gemser and Visscher, 2010; Clemente, Martins, Wong, Calamaras and Mendes 2015; Maneiro-Dios and Amatria, 2018).

The wingers (RW and LW) have longer patterns, as well as a greater number of bifurcations. In addition, they frequently show greater relationships with more offensive players on their own side of the pitch. This would confirm the suggestion put forward by Teixeira et al. (2011), who state that the players preferably use their dominant leg to handle the ball, becoming intermediary players within their area of intervention. However, the volume and characteristics of the behavior of both players, although similar, are not the same. In our case, it is the RS player who performs the most interactions with other teammates and a greater number of bifurcations than his opponent. This will not always be the same in all teams, since it will depend a lot on the profile and characteristics of the players who occupy these positions (Bojinov and Bornn, 2016).

In general, studies that have tried to relate the success achieved in the attack phase with the number of players participating in it seem to indicate that the number of players involved in the action is small (Castelo, 1994). Success in the attack phase depends on both the type of relationships that are established and the organization zones of the game. It has been found in our study that successful actions are short and involve the participation of few players, represented in short patterns in the retrospective perspective. We think that the style or model of play used by the teams should be taken into account. This is confirmed by the study by Garganta (1997), which compares patterns of behavior in play that ends in goal of five European teams at the highest level.

It is universally accepted that passing is a key technical element of offensive play. It allows the team to progress with the ball and thereby look for a goal efficiently. In relation to the passing category, the team under study made a total of 2966 passes (a mean of 296.6 passes per game). These data are similar to those provided by Maya-Jariego and Bohórquez (2013) in a study of First Division teams from the same country (230 and 281 per team). Armatas (2009) points out that the difference between the best and the worst classified teams in a competition usually lies in the number of passes that they perform. The best tend to make twice as many passes as the worst. The number of passes alone is an important aspect, but in order to understand its true significance it is necessary to include the criterion of their quality. The teams that present a very high percentage of accurate passes are usually those that perform best in tournaments (Casais, Lago, Lago, Iglesias and Gómez, 2011). However, the team's performance level criterion is not the only variable that differentiates teams by virtue of the number of passes they make. In this same regard, when we study the final of the European Championship held in France in 2016, we can observe differences in the number of passes performed by the two teams that played (France 700, Portugal 500) (MartínGonzález, Díaz, Ramos, Arriaza, Da Silva and García- Manso, 2017).

If we understand volume of passes as an important aspect for identifying a team's game model, we observe that the data obtained are similar. Therefore, we should look for other aspects that serve as an identifier of these models and differentiate the play of some teams from that of others. 
The two midfielders (RMIF and LMIF) have the greatest weight in this type of actions, with percentages of $12.51 \%$ and $12.27 \%$, respectively. The data obtained coincide with those provided by Sánchez-Flores (2014), who stated that the players who occupy positions in the creation area account for $15 \%$ of the passes performed. Other authors such as Carlin (2010) and Bloomfield, Remco and O'Donoghue (2007) consider these players as key elements of the game system, so they must present high technical and tactical abilities with which to handle the numerous and varied situations they face during the game.

In relation to the Shots category (SHOOT), there were a total of 152 (15.2 per game). The data obtained are lower than those found by Castellano and Hernández-Mendo (2000), with an average of 26.9 shots per match, Perea (2008) with 24.7 per game, and Robles (2012) with 23.4. The players who make the most shots are the forwards, which coincides with the aforementioned study by Robles and Castellano (2012). A possible explanation could be established for the team analyzed in our study.

Buraczewski and Cicirko (2011) establish higher total frequencies and percentages, in both total shots and goals, for the teams that achieve success compared with those that do not. Also, Szwarc (2004) records more shots for the winning teams and also with greater effectiveness, similar to the data of Yamanaka, Hughes and Lott (1993) and Bishovets, Gadjiev and Godik (1993). However, what a greater number of shots does not ensure is the idea of a combinative game, since most of the shots at goal are achieved in short moves (Hughes and Churchill, 2005), although it is true that having more possession time guarantees a greater number of attack situations (Gómez and Álvaro, 2003).

\section{CONCLUSIONS}

Based on our data, we can affirm that the use of evaluation techniques such as observational methods and sequential analysis has allowed us to approach the study of game dynamics in competition and build a conceptual map of the interactions that are established between members of a soccer team. The study of the game action has allowed us to verify the stable relationships that are manifested in the attacking behavior of the team analyzed, rejecting the idea of a random behavior in the communications between players. Occupation of the pitch and attempts to get a goal were two of the most important aspects identified in this sample. The spatial location of the players within the system conditions the possible connections between players. These are mediated by the different game systems used and by the tactical variants that are developed during a match. In the matches evaluated, there is an increase in the chances of success (winning the match) as the number of shots increases, especially those aimed between the goalposts.

\section{REFERENCES}

Anguera, M.T. (1990). Metodología observacional. In J. Arnau, M. T. Anguera and J., Gómez Benito. Metodología de la investigación en ciencias del comportamiento. 125-236. Murcia: Universidad de Murcia.

Anguera, M.T. and Blanco, A. (2003). Registro y codificación en el comportamiento deportivo. En A. Hernández Mendo, Revista de Psicología del Deporte (Vol. 2) Metodología 6-34.

Anguera, M.T., Blanco-Vilaseñor, A., Hernández Mendo, A. and Losada, J.L. (2014). Diseños Observacionales: Ajuste y aplicación en psicología del deporte. Cuadernos de psicología del deporte, 11(2), 63-76.

Anguera, M.T. and Hernández-Mendo, A. (2015). Técnicas de análisis en estudios observacionales en ciencias del deporte. Cuadernos de Psicología del Deporte, 15(1), 13-30. https://doi.org/10.4321/S1578-84232015000100002 
Araujo D., Duarte R., Davids, K. and Hristovski, R. (2006). The ecological dynamics of decision making in sport. Psychology of Sport and Exercise. Volume 7, Issue 6, November 653-676. https://doi.org/10.1016/i.psychsport.2006.07.002

Armatas, V; Yannakos, A; Zaggelidis, G, Skoufas, D; Papadopoulou, S. and Fragkos, N. (2009). Journal of Physical Education and Sport, 23(2), 1-5.

Arriaza, J.E. and Zuñiga, D.M. (2016). Soccer as a Study Case for Analytic Trends in Collective Sports Training: A Survey. International Journal of Performance Analysis in Sport, 16(1), 171-190. https://doi.org/10.1080/24748668.2016.11868879

Bakeman, R. and Gottman, J.M. (1997). Observing interaction: An introduction to sequential analysis. Cambridge University Press. https://doi.org/10.1017/CB09780511527685

Barreira, D., Garganta, J., Castellano, J., Prudente, J. and Anguera, M.T. (2014). Evolución del ataque en el fútbol de élite entre 1982 y 2010: Aplicación del análisis secuencial de retardos. Revista de Psicología del Deporte, 23(1), 139-146.

Barreira, D., Ribeiro, R., Garganta, J. and Anguera, M. T. (2010). Attacking Game-Patterns in Soccer. A Sequential analysis of European Championship 2008. Paper presented at the IV European Congress of Methodology: EAM-SMABS 2010, Potsdam, Germany.

Bishovets, A., Gadjiev, G. and Godik, M. (1993). Computer Analysis of effectiveness of collective technical and tactical moves of footballers in the matches of 1998 Olympics and 1990 World Cup. En T. Reilly, J. Clarys, and A. Stibbe, Science and Football II (pp. 232-238). London: E and F Spon.

Blanco-Villaseñor, A. and Anguera, M. T. (2003). Calidad de los datos registrados en el ámbito deportivo. In Hernández Mendo, Psicología del Deporte: Volumen II. Metodología (págs. 35-73). Buenos Aires: Tulio Guterman.

Bloomfield, J., Remco, P. and O'Donoghue, P. (2007). Physical Demands of Different Positions in FA Premier League Soccer. Journal Sports Science and Medicine. Mar; 6(1): 63-70.

Bojinov, I. and Bornn, L. (2016) The pressing game: optimal defensive disruption in soccer. http://www.sloansportsconference.com/content/the-pressing-game-optimal- defensive-disruption-insoccerl

Buraczewski, T. and Cicirko, L. (2011). The differences in the effectiveness of football game between the best teams in XII European Championship in 2008. Book of abstracts of the 7th World Congress on Science and Football. Japan: Nagoya.

Carling, C. (2010). Analysis of physical activity profiles when running with the ball in a professional soccer team. Eur J of Sport Sci, 28 (3), 319-326. https://doi.org/10.1080/02640410903473851

Casáis, L., Lago, C., Lago, J., Iglesias, S. and Gómez M. (2011). Indicadores de rendimiento competitivo que diferencian ganadores y perdedores de la liga española. Fútbol pf: Revista de Preparación física en el fútbol. No. 2.

Castelo, J. (1994). Futebol. Modelo tecnico-táctico do jogo. Lisboa: Ediçoes FMH.

Castellano, J. and Hernández-Mendo, A. (2000). Análisis secuencial en el fútbol de rendimiento. Psicothema, 12(2), 117-121.

Castellano, J., Perea, A., Alday, L. and Hernández-Mendo, A. (2008). The measuring and observation tool in sports. Behavior Research Methods, 40(3), 898-905. https://doi.org/10.3758/BRM.40.3.898

Clemente, F., Martins, F., Wong, D., Kalamaras, D. and Mendes, R. (2015). Midfielder as the prominent participant in the building attack: a network analysis of national teams in FIFA World Cup 2014. Int. J. Peform. Anal. Sport 15, 704-722. https://doi.org/10.1080/24748668.2015.11868825

Cohen, J. (1960). A coefficient of agreement for nominal scales. Educational and Psychological Measurement, 41, 687-699. https://doi.org/10.1177/001316446002000104 
Couceiro, M.S., Clemente, F.M., Martins, F.M. and Machado, J.A. T. (2014). Dynamical stability and predictability of football players: the study of one match. Entropy, 16(2), 645-674. https://doi.org/10.3390/e16020645

De Saá-Guerra, Y.D., Martín-González, J.M., Arjonilla, N., Sarmiento, S., Rodríguez-Ruiz, D. and GarcíaManso, J.M. 2013. Analysis of competitiveness in the NBA regular seasons. Ugdymas, Kûno Kultûra, Sportas, 1(80), 17-21.

Duarte, R., Araújo, D., Folgado, H., Esteves, P., Marques, P. and Davids, K. (2013). Capturing complex, non-linear team behaviours during competitive football performance. Journal of Systems Science and Complexity, 26(1), 62-72. https://doi.org/10.1007/s11424-013-2290-3

Duch, J., Waitzman, J. and Amaral L. (2010). Quantifying the performance of Individual Players in a Team Activity. PloS ONE, Vol 5(6) https://doi.org/10.1371/journal.pone.0010937

Gabín, B., Camerino, O., Anguera, M.T. and Castañer, M. (2012). Lince multiplatform sport Analysis software. Procedia - Social and Behavioral Sciences (46), 4692-4694. https://doi.org/10.1016/i.sbspro.2012.06.320

Garganta, J. (1997). Modelaçao táctica do jogo de futebol. Estudio da organizaçao da fase ofensiva em equipos de alto rendimento. Universidad do Porto, Porto, Portugal.

Garganta, J. (2000). Análisis del juego en el fútbol. El recorrido evolutivo de las concepciones, métodos e instrumentos. Revista de entrenamiento deportivo, XIV (2), 6-13.

Garganta, J. (2009). Trends of tactical performance analysis in team sports: bridging the gap between research, training and competition. Revista Portuguesa de Ciências do Desporto, 9(1), 81-89. https://doi.org/10.5628/rpcd.09.01.81

Gómez M. and Álvaro, J. (2003). El tiempo de posesión como variable no determinante del resultado en los partidos de fútbol. El Entrenador Español, 97, 39-5.

Grant, A., Williams, M., Reilly, T. and Borrie, A. (1998). Analysis of the Successful and Unsuccessful Teams in the 1998 World Cup. Insight (FA Coaches), 2 (1), 21-24.

Gréhaigne, J.F. (2001). La organización del juego en el fútbol. Barcelona: INDE.

Griffiths, D. (1999). An analysis of France and their opponents at the 1998 Soccer World Cup with specific reference to playing patterns. (unpublished doctoral thesis), University of Wales Institute Cardiff, Cardiff, Wales.

Gyarmati, L., Kwak, H. and Rodriguez, P. (2014). Searching for a Unique Style in Soccin Proceedings of the 2014 KDD Workshop on Large-Scale Sports Analytics. arXiv: 1409.0308.er.

Hughes, M. and Churchill, S. (2005). Attacking profiles of successful and unsuccessful team in Copa América 2001. In T. Reilly, J. Cabri, and D. Araújo, Science and Football V (pp. 219-224). London: Routledge.

Kannekens, R., Elferink-Gemser, M. and Visscher, C. (2010). Positioning and deciding: key factors for talent development in soccer. Scand. J. Med. Sci. Sports 21, 846-852. https://doi.org/10.1111//.1600-0838.2010.01104.x

Kent, R. and Foster, S. (1977). Direct observation procedures: methodological issues in naturalist settings. En A. Ciminero, D. Calhovn and Adams, Handbook of Behavioural Assessment. (279-328). New York: John Wiley and Sons.

Lago, C. (2008). El análisis del rendimiento en los deportes de equipo. Algunas consideraciones metodológicas. Acción Motriz (1), 41-58.

Lames, M. and McGarry, T. (2007). On the search for reliable performance indicators in game sports. Int. J. Perform. Anal. Sport, 7, 62-79. https://doi.org/10.1080/24748668.2007.11868388

Landis, J. and Koch, G. (1977). The measurement of observer agreement for categorical data. Biometrics, 33, 159-174. https://doi.org/10.2307/2529310 
Machado, J., Barreira, D. and Garganta, J. (2011). Attacking game-patterns in Soccer. A sequential analysis of the World Cup 2010 winner team. In M. Hughes, H. Dancs, K. Nagyváradi, T.

Maneiro-Dios and Amatria, M. (2018). Polar Coordinate Analysis of Relationships With Team-mates, Areas of the Pitch, and Dynamic Play in Soccer: A Study of Xabi Alonso.

Martín González, J.M., Díaz Díaz, R., Ramos Verde, E., Arriaga Ardales, E., da Silva Grigoletto, M. and García Manso, J.M. (2017). Topological properties and dynamics of nets game shown by France and Portugal in the final of European soccer cup 2016. Motricidade 13 (S1), 101-112.

Maya Jariego, I., and Bohórquez, M.R. (2013). Análisis de las redes de distribución de balón en fútbol: pases de juego y pases de adaptación. REDES - Revista hispana para el análisis de redes sociales 24 (2), 135-155.

Pena, J.L. and Touchette, H. (2012). A network theory analysis of football strategies. Ar Xiv: 1206.6904.

Perea, A. (2008). Análisis de las acciones colectivas en el fútbol de rendimiento. Doctoral Thesis: Universidad del País Vasco.

Quera, V., Bakeman, R. and Gnisci, A. (2007). Observer agreement for event sequences: Methods and software for sequence alignment and reliability estimates. Behavior Research Methods 39 (1), 3949. https://doi.org/10.3758/BF03192842

Robles, F. (2012). Observación y análisis de las acciones ofensivas de la selección de fútbol en la Eurocopa y el Mundial de 2010. Doctoral Thesis: Vitoria Gasteiz.

Robles, F. and Castellano, J. (2012). Comparación entre el juego ofensivo de la selección española de fútbol y sus rivales en la Eurocopa 20808 y mundial. Revista Iberoamericana de psicología del ejercicio y el deporte. Vol.7, no. 2 pp. 323-338.

Sánchez Flores, J. (2014). Análisis del desarrollo del juego de fútbol 11, desde la perspectiva de los sistemas complejos. Doctoral Thesis: Universidad de Las Palmas de Gran Canaria.

Silva, A., Sánchez Bañuelos, F., Garganta, J. and Anguera, M.T. (2005). Patrones de juego en el fútbol de alto rendimiento. Análisis secuencial del proceso ofensivo en el campeonato del mundo CoreaJapón 2002. Cultura, Ciencia y Deporte, 1(2): 65-72.

Stein, M., Janetzko, H., Seebacher, D., Jäger, A., Nagel, M., Hölsch, J., Kosub, S., Schrek, T., Keim, D.A. and Grossniklaus, M. (2017). How to make sense of team sport data: From acquisition to data modeling and research aspects. Data, 2(1), https://doi.org/10.3390/data2010002

Stöckl, M., Plück, D. and Lames L. (2017). Modelling game sports as complex systems - application of recurrence analysis to golf and soccer. Mathematical and Computer Modelling of Dynamical Systems, 23(4), 399-415. https://doi.org/10.1080/13873954.2017.1336635

Szwarc, A. (2004). Effectiveness of Brazilian and German teams and the teams defeated by them during the 17th FIFA World Cup. Kinesiology, 36 (1), 83-89.

Teixeira, L., Dalton L., Guimarães R., Cavalcanti, S. (2011). Leg Preference and Interlateral Asymmetry of Balance Stability in Soccer Players. Research Quaterly for Exercise and Sport. 82(1), 21-27. https://doi.org/10.1080/02701367.2011.10599718

Yamanaka, K., Hughes, M. and Lott, M. (1993). An analysis of playing patters in the 1990 World Cup for association football. In J. Reilly, J. Clarys, and A. Stibbe (Edits.), Science and Football II (pp. 206214). London: E and FN Spon.

\section{(@)}

This title is licensed under a Creative Commons Attribution-NonCommercial-NoDerivs 4.0 Unported License. 